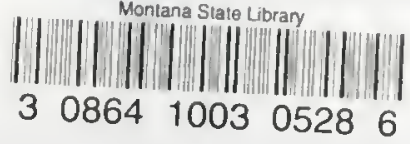

\title{
BIOLOGICAL INTEGRITY OF STREAMS IN THE BLACKFOOT RIVER TMDL PLANNING AREA BASED ON THE STRUCTURE AND COMPOSITION OF THE BENTHIC ALGAE COMMUNITY
}

\author{
Prepared for: \\ State of Montana \\ Department of Environmental Quality \\ P.O. Box 200901 \\ Helena, Montana 59620-0901 \\ Project Officer: Andrew Welch \\ DEQ Contract No. 200012-10
}

Prepared by:

Loren L. Bahls, Ph.D.

Hannaea

1032 Twelfth Avenue

Helena, Montana 59601

STATE GUCUNEI'TS COLLEC+.'

May 19, 2004

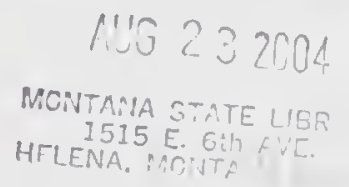


중

- 


\section{Summary}

In September and October of 2003, periphyton samples were collected from 30 sites on 19 streams in the Blackfoot River TMDL planning area in west central Montana for the purpose of assessing whether these streams are water-quality limited and in need of TMDLs. The samples were collected following MDEQ standard operating procedures, processed and analyzed following standard methods for periphyton, and evaluated following modified USEPA rapid bioassessment protocols for wadeable streams.

Siltation index values for Black Bear Creek, lower Buffalo Gulch, lower Douglas Creek, and lower Washington Creek suggest severe impairment from sedimentation and nonsupport of aquatic life uses. Siltation index values for Blanchard Creek, Wales Creek, Frazier Creek, upper Buffalo Gulch, and upper Washington Creek indicate moderate impairment from sedimentation and partial support of aquatic life uses. The low pollution index for Black Bear Creek indicates moderate impairment from excessive organic nutrients and only partial support of aquatic life uses. Diatom metrics suggest minor impairment from both organic loading and sedimentation at most of the remaining Blackfoot tributary sites.

Larger than normal percentages of teratological diatom cells $(>1 \%)$ suggest that elevated concentrations of heavy metals may be present in Richmond Creek and at the upper site on the West Fork of the Clearwater River. Twenty-two sites supported smaller percentages of abnormal diatom cells $(<1 \%)$ and 6 sites had none.

Diatoms were present in all of the samples. Most of the 34 major diatom species are either sensitive to organic pollution or only somewhat tolerant of organic pollution. Only one of the major diatom species-Nitzschia palea-is most tolerant of organic pollution and this species was most abundant in Black Bear Creek.

In general, diatom species richness, diversity, and equitability were excellent. Most sites had more than 40 species and diversity values greater than 4.00. One site (lower Murray Creek) had 73 species and a diversity index of 4.99 , which are exceptional values for a mountain stream. High diatom diversity in these streams suggests moderate nutrient enrichment (little competition for available nutrients) and the absence of extreme natural stressors, such as steep gradients, fast currents, low light, low nutrients, and/or constant cold temperatures. Only one site-upper Douglas Creek-had a low diversity value that indicates unusual stress. This was also the only site where the dominant species contributed more than half of the diatom cells. The cause of stress in upper Douglas Creek was probably excess inorganic nutrients.

Streams where nitrogen-fixing cyanobacteria were common include the West Fork of the Clearwater River (both sites), Deer Creek (both sites), Blanchard Creek, Buffalo Gulch (upper site), Washington and Jefferson Creeks (upper sites), and Seven-Up Pete Creek. Nitrogen-fixing diatoms in the order Rhopalodiales accounted for more than $2 \%$ of the cells in the West Fork of the Clearwater River (both sites), Deer Creek (both sites), Black Bear Creek, Blanchard Creek, Jefferson Creek (upper site), and Seven-Up Pete Creek. Nitrogen is most likely the limiting nutrient at these sites. 


\section{Introduction}

This report evaluates the biological integrity ${ }^{1}$, support of aquatic life uses, and probable causes of stress or impairment to aquatic communities at 30 sites on 19 streams in the Blackfoot River TMDL Planning Area of west central Montana. The purpose of this report is to provide information that will help the State of Montana determine whether these streams are waterquality limited and in need of TMDLs.

The federal Clean Water Act directs states to develop water pollution control plans (Total Maximum Daily Loads or TMDLs) that set limits on pollution loading to water-quality limited waters. Water-quality limited waters are lakes and stream segments that do not meet waterquality standards, that is, that do not fully support their beneficial uses. The Clean Water Act and USEPA regulations require each state to (1) identify waters that are water-quality limited, (2) prioritize and target waters for TMDLs, and (3) develop TMDL plans to attain and maintain water-quality standards for all water-quality limited waters.

Evaluation of aquatic life use support in this report is based on the species composition and structure of periphyton (a.k.a. benthic algae, phytobenthos) communities at 30 sites on 19 streams that were sampled in September and October of 2003. Periphyton is a diverse assortment of simple photosynthetic organisms called algae that live attached to or in close proximity of the stream bottom. Some algae form long filaments or large gelatinous colonies that are conspicuous to the unaided eye. However, most algae, including the ubiquitous diatoms, can be seen and identified only with the aid of a microscope. The periphyton community is a basic biological component of all aquatic ecosystems. Periphyton accounts for much of the primary production and biological diversity in Montana streams (Bahls et al. 1992). Plafkin et al. (1989) and Barbour et al. (1999) list several advantages of using periphyton in biological assessments.

\footnotetext{
'Biological integrity is defined as "the ability of an aquatic ecosystem to support and maintain a balanced, integrated, adaptive community of organisms having a species composition, diversity, and functional organization comparable to that of natural habitats within a region" (Karr and Dudley 1981).
} 


\section{Project Area and Sampling Sites}

The project area is located mostly within the Middle Rockies Ecoregion (USEPA 2000). Some of the north side tributaries of the Blackfoot River head in the Canadian Rockies Ecoregion (USEPA 2000). The Blackfoot River begins at Rogers Pass north of Helena and flows west for about 100 miles to its confluence with the Clark Fork River at Bonner, Montana. The surface geology of the watershed is complex, consisting mostly of Precambrian Belt Series Rocks in the uplands and Tertiary basin fill in the Blackfoot Valley (Renfro and Feray 1972). Climax vegetation consists of alpine tundra at the highest elevations, mixed conifer forest at intermediate elevations, and mixed grassland/sagebrush steppe in the Blackfoot Valley near Ovando. The main land uses are recreation, logging, ranching, and mining.

Periphyton samples were collected at 30 sites on 19 tributaries of the Blackfoot River (Table 1). All sites are in USGS HUC 17010203 and are classified B-1 in the Montana Surface Water Quality Standards.

\section{Methods}

Periphyton samples were collected following standard operating procedures of the MDEQ Planning, Prevention, and Assistance Division. Using appropriate tools, microalgae were scraped, brushed, or sucked from natural substrates in proportion to the importance of those substrates at each study site. Macroalgae were picked by hand in proportion to their abundance at the site. All collections of microalgae and macroalgae were pooled into a common container and preserved with Lugol's (IKI) solution.

The samples were examined to estimate the relative abundance of cells and rank by biovolume of diatoms and genera of soft (non-diatom) algae according to the method described in Bahls (1993). Soft algae were identified using Smith (1950), Prescott (1962, 1978), John et al. (2002), and Wehr and Sheath (2003). These books also served as references on the ecology of the soft algae, along with Palmer $(1969,1977)$. 
After the identification of soft algae, the raw periphyton samples were cleaned of organic matter using sulfuric acid, potassium dichromate, and hydrogen peroxide. Then permanent diatom slides were prepared using Naphrax ${ }^{\mathrm{TM}}$, a high refractive index mounting medium, following Standard Methods for the Examination of Water and Wastewater (APHA 1998). At least 400 diatom cells ( 800 valves) were counted at random and identified to species. The following were the main taxonomic references for the diatoms: Krammer and Lange-Bertalot 1986, 1988, 1991 a, 1991b; Lange-Bertalot 1993, 2001; Kranmer 1997a, 1997b, 2002; Reichardt 1997, 1999. Diatom naming conventions followed those adopted by the Integrated Taxonomic Information System (http://www.itis.usda.gov). For taxa not yet included in ITIS, naming conventions followed those adopted by the Academy of Natural Sciences for USGS NAWQA samples (Morales and Potapova 2000). Van Dam et al. (1994) was the main ecological reference for the diatoms.

The diatom proportional counts were used to generate an array of diatom association metrics. A metric is a characteristic of the biota that changes in some predictable way with increased human influence (Barbour et al. 1999). Diatoms are particularly useful in generating metrics because there is a wealth of information available in the literature regarding the pollution tolerances and water quality preferences of common diatom species (e.g., Lowe 1974, Beaver 1981, Lange-Bertalot 1996, Van Dam et al. 1994).

Values for selected metrics were compared to biocriteria (numeric thresholds) developed for streams in the Rocky Mountain ecoregions of Montana (Table 2). These criteria are based on metric values measured in least-impaired reference streams (Bahls et al. 1992) and metric values measured in streans that are known to be impaired by various sources and causes of pollution (Bahls 1993). The criteria in Table 2 are valid only for samples collected during the summer field season (June 21-September 21). [Note: About half of the Blackfoot TMDL periphyton samples were collected after September 21.] These criteria distinguish among four levels of stress or impairment and three levels of aquatic life use support: (1) no impairment or only minor impairment (full support); (2) moderate impairment (partial support); and (3) severe impairment (non-support). These impairment levels correspond to excellent, good, fair, and poor 
biological integrity, respectively. In cold, high-gradient mountain streams, natural stressors will often mimic the effects of man-caused impairment on some metric values.

\section{Quality Assurance}

Several steps were taken to assure that the study results are accurate and reproducible. Upon receipt of the samples, station and sample attribute data were recorded in the Montana Diatom Database and the samples were assigned a unique number, e.g., 3031-01. The first part of this number (3031) designates the sampling site (Monture Creek near mouth) and the second part (01) designates the number of periphyton samples that that have been collected at this site for which data have been entered into the Montana Diatom Database.

Sample observations and analyses of soft (non-diatom) algae were recorded in a lab notebook along with information on the sample label. A portion of the raw sample was used to make duplicate diatom slides. The slides used for the diatom proportional counts will be deposited in the Montana Diatom Collection at the University of Montana Herbarium (MONTU) in Missoula. Duplicate slides will be retained by Hannaea in Helena. Diatom proportional counts have been entered into the Montana Diatom Database.

\section{Results and Discussion}

Results are presented in Tables 3, 4, 5, and 6 which are located near the end of this report following the references section. Appendix A contains a diatom report for each sample. Each diatom report includes an alphabetical list of diatom species in that sample and their percent abundances, and values for 66 different diatom metrics and ecological attributes.

\section{Sample Notes (Table 3)}

Notes on the contents and condition of each sample are recorded in Table 3. Most samples contained varying amounts of sediment and plant material other than algae. 


\section{Non-Diatom Algae (Table 4)}

Thirty-two genera representing five divisions of non-diatom algae were found in samples that were collected from tributaries of the Blackfoot River (Table 4). Divisions represented by the most genera were Chlorophyta or green algae (17 genera) and Cyanophyta or cyanobacteria (10 genera). The Division Chrysophyta (yellow-green algae) was represented by two genera and the Divisions Rhodophyta (red algae) and Phaeophaeta (brown algae) were represented by one genus each.

Green algae were found in all but 5 samples and cyanobacteria were found in all but 5 samples. Yellow-green algae were found in 8 samples and the red alga Audoninella was found in 11 samples. Heribaudiella fluviatilis, a rare freshwater brown alga [most other species of brown algae are marine], was found in 7 samples and was abundant in Monture Creek, the West Fork of the Clearwater River, and upper Jefferson Creek. The number of genera of non-diatom algae ranged from 0 in lower Murray Creek to 15 at the lower site on the West Fork of the Cleanvater River.

Nitrogen-fixing Algae. Cyanobacteria that possess a certain type of specialized cell (heterocyst) are capable of fixing molecular or atmospheric nitrogen under aerobic conditions. These algae have a competitive advantage in waters where nitrogen is in short supply relative to phosphorus and other nutrients. Among tributaries of the Blackfoot River, blue-green algae with heterocysts include Anabaena, Calothrix, Nostoc, and Tolypothrix. Streams where one or more of these genera were common, frequent, or abundant are: West Fork of the Cleanvater River (both sites), Deer Creek (both sites), Blanchard Creek, Buffalo Gulch (upper site), Washington and Jefferson Creeks (upper sites), and Seven-Up Pete Creek. Nitrogen is most likely the limiting nutrient at these sites.

Mat-forming Filamentous Algae. Large standing crops of filamentous algae can interfere with swimming, boating, fishing, and other water uses. Algal genera in tributaries of 
the Blackfoot River that are known to produce nuisance growths in North American waters are Cladophora, Oedogonium, Oscillatoria, Rhizoclonium, Spirogyra, Stigeoclonium, and Ulothrix (Wehr and Sheath 2003). Streams where one or more of these genera were dominant or abundant in periphyton samples are: Monture Creek, Yourname Creek, West Fork Clearwater River, Blanchard Creek, Rock Creek, Douglas Creek, and Braziel Creek. Among the streams represented in this sample set, these are most likely to support nuisance growths of mat-forming filamentous algae.

Pollution-tolerant Algae. Palmer (1969) listed 60 algal genera that are most tolerant of organic pollution. Genera of non-diatom algae in this sample set that are among the top 22 on Palmer's list are Oscillatoria (\#2), Scenedesmus (\#4), Siigeoclonium (\#8), Ankistrodesmus (\#10), Phormidium (\#12) Closterium (\#16), Spirogyra (\#21), and Anabaena (\#22). Streams where one or more of these genera were abundant or dominant are: Monture Creek, West Fork Clearwater River, Blanchard Creek, Rock Creek, and Douglas Creek. These streams are the ones that most likely receive the heaviest loads of organic matter. Genera among the 22 most pollution-tolerant algae were common or frequent at several more sites.

Other Indicator Algae. When abundant, certain genera of algae can provide useful clues about environmental conditions. The two genera of chrysophytes that were present in these samples are both good indicator algae. Tribonema, which is sensitive to organic pollution and prefers cool waters, was most abundant in upper Deer Creek, upper Monture Creek, and in the West Fork of the Clearwater River. Vaucheria, another chrysophyte, requires steady flows of cool water. Vaucheria was frequent in Buffalo Gulch (lower) and occasional in Frazier Creek and lower Deer Creck.

The filamentous green alga Mougeotia has often been reported to increase in abundance in lakes that are subject to atmospheric deposition and undergoing acidification. Among study sites in the Blackfoot River TMDL planning area, Mougeotia occurred infrequently and was common only in the West Fork of the Clearwater River and in Rock Creek. 


\section{Diatoms (Table 5)}

Diatoms were present in all of the samples. Most of the 34 major diatom species in tributaries of the Blackfoot River are either sensitive to organic pollution or only somewhat tolerant of organic pollution. Only one of the major diatom species (Nitzschia palea) is most tolerant of organic pollution and this species was most abundant in Black Bear Creek (Table 5).

In general, diatom species richness, diversity, and equitability were excellent. Most sites supported more than 40 species and diversity values in excess of 4.00 . One site (lower Murray Creek) had 73 species and a diversity index of 4.99 . These are exceptionally high values for a mountain stream. Only one site-upper Douglas Creek-had a diversity value that indicates unusual stress. This was also the only site where the dominant species contributed more than half of the cells to the diatom assemblage (Table 5). The cause of stress in upper Douglas Creek was probably excess inorganic nutrients.

High diatom diversity in these samples suggests the absence of extreme natural stressors, such as steep gradients, fast currents, low light, low nutrients, and constant cold temperatures, which may prevail in the extreme upper reaches of these streams. The abundance of non-motile, free-living taxa (Diatoma spp., Fragilaria spp., Melosira varians, Psendostarosira brievistriata, Staurosira construens, and Synedra spp.), attached species (Achnanthidium spp., Cocconeis placentula, Rhoicosphenia abbreviata), and motile, free-living taxa (Navicula spp., Nitzschia spp., Surirella minuta) suggests a wide variety of substrates, gradients, and current velocities. The disturbance index at most sites was relatively low, which suggests moderate gradients and slower current velocities than most mountain streams (Table 5).

Besides the absence of natural stressors and the presence of complex microhabitats, high diatom diversity in these streams also suggests moderate nutrient enrichment (little competition for available nutrients). Pollution index values, which indicate the amount of organic loading, are generally low for mountain streams. Many are at or below the threshold for minor impairment. 
Similarly, siltation index values tend to be higher in Black foot tributaries than in most mountain streams.

Most of the sites supported teratological (deformed or physically abnormal) diatom cells. In large numbers, abnormal cells may indicate metals toxicity. However, the percentage of abnormal cells was within acceptable limits at all sites. The largest percentage of abnormal cells (1.74\%) was recorded in Richmond Creek (Table 5).

The similarity index ("percent community similarity") measures the cumulative percentage of cells of each taxon that are shared by two stream sites. The similarity index can be used to gauge the degree of environmental change that occurs between sites on the same stream. Similarity index values for Blackfoot tributaries suggest that ecological changes between adjacent sites on the same stream varied from un-measurable $(>60 \%$ between the middle and lower Monture Creek sites) to extreme ( $<20 \%$ between the two sites on Rock Creek).

The diatom order Rhopalodiales includes genera (Epithemia and Rhopalodia) that are known to harbor nitrogen-fixing endosymbionts within their cells. These symbiotic nitrogenfixers are single-celled cyanobacteria (blue-green algae). Nitrogen is likely the limiting nutrient in waters that support large numbers of diatoms in the order Rhopalodiales. Among tributaries to the Blackfoot River, diatoms in the order Rhopalodiales accounted for more than $2 \%$ of the cells at the following sites: West Fork Clearwater River (both sites), Deer Creek (both sites), Black Bear Creek, Blanchard Creek, Jefferson Creek (upper site), and Seven-Up Pete Creek.

The following paragraphs highlight the key findings for each stream and each site based upon the major diatom species and core diatom metrics in Table 5.

Monture Creek. Except for a few teratological cells and slightly elevated disturbance index values, diatom metrics indicate that Monture Creek had excellent biological integrity, no impairment, and provided full support to aquatic life uses. Similarity index values indicate little environmental change between the upper and middle sites and virtually no change between the middle and lower sites. 
Kleinschmidt Creck. Kleinschmidt Creek also supported a few abnormal diatom cells and had a slightly elevated disturbance index (\% Achnanthidium minutissimum), which indicates minor stress that may be natural in origin.

Yourname Creek. This site had a depressed pollution index and an elevated siltation index, which indicate minor impairment from organic loading and sedimentation, respectively. Three teratological diatom cells were counted here.

Richmond Creek. This stream had an elevated siltation index and supported the largest percentage of abnormal diatoms (1.74\%) of all the Blackfoot tributaries. However, both values suggest only minor impairment and full support of aquatic life uses.

West Fork Clearwater River. The upper site had a slightly elevated siltation index and supported the second largest percentage of abnormal diatoms (1.19\%). Both values indicate only minor impairment and full support of aquatic life uses. Diatom metrics at the lower site indicate excellent biological integrity and no impairment of aquatic life uses. The similarity index indicates that a moderate amount of environmental change occurred between the two sites.

Deer Creek. The upper site had a slightly elevated siltation index that indicates minor impairment from sedimentation. Judging from the depressed pollution index and the large percentage of the eutraphentic species Melosira varians, the lower site suffered minor impairment from excess organic loading and elevated concentrations of inorganic nutrients. The similarity index between the two sites suggests that a moderate amount of environmental change occurred between them.

Blanchard Creek. A large percentage of highly motile diatoms at this site, including Nitzschia fonticola, suggest moderate impairment and only partial support of aquatic life uses due to excessive sedimentation. Blanchard Creek also had lower diatom species richness and diversity values than most other sites in the sample set, and the pollution index was just above the threshold for minor impairment. 
Wales Creek. The large percentage of motile diatoms in Wales Creek indicates moderate impairment from sedimentation and only partial support of aquatic life uses. The slightly depressed pollution index suggests minor impaiment from organic loading.

Rock Creek. Diatom metrics suggest that both sites had good biological integrity and provided full support to aquatic life uses. Rock Creek had a very distinctive diatom flora that included two species that are seldom recorded in North America: Gomphonema designatum and Distrionella incognita. The latter is restricted to streams that head in the Canadian Rockies Ecoregion. The two sites on Rock Creek supported very different diatom floras.

Frazier Creek. A large percentage of motile diatoms here suggest moderate impairment and partial support of aquatic life uses due to sedimentation. The siltation index here approaches but does not exceed the threshold for severe impairment and non-support of aquatic life uses. The pollution index for Frazier Creek is just below the threshold for minor impairment from organic loading.

Buffalo Gulch. Both sites on Buffalo Gulch support elevated percentages of motile diatoms. The siltation index at the upper site just exceeds the threshold for moderate impairment and partial support of aquatic life uses. The siltation index at the lower site exceeds the threshold for severe impairment and non-support of aquatic life uses. The pollution index indicates that both sites suffer minor impairment from elevated organic loading. The two sites on Buffalo Gulch shared about half of their diatom assemblages, which indicates that only minor changes in environmental conditions occurred between them.

Black Bear Creek. This site had the highest siltation index and the lowest pollution index of all sites in the sample set. The very large percentage of highly motile diatoms indicates severe impairment and non-support of aquatic life uses due to sedimentation. Large numbers of Nitzschia palea, a pollution tolerant species, indicates elevated concentrations of nitrogenous organic matter, and the resulting low pollution index suggests moderate impairment and partial support of aquatic life uses. 
Murray Creek. Diatom metrics indicate that Murray Creek had good biological integrity and provided full support of aquatic life uses. Slightly elevated siltation index values suggest minor impairment from sedimentation. Both sites also supported large numbers of Planothidium spp., which are adapted to living attached to sand grains. A low pollution index value at the lower site suggests minor impairment from organic loading. The two sites on Murray Creek shared about half of their diatom assemblages.

Douglas Creek. Diatom metrics indicate progressively increasing organic loading and sedimentation in a downstream direction on Douglas Creek. The upper site was dominated by Cymbella excisa, an eutraphentic species that favors elevated concentrations of inorganic nutrients. The large percentage of this diatom resulted in the lowest diversity index (2.64) of all the sites in the sample set. Otherwise, this site had normal metric values for a mountain stream. The middle site was floristically much different from the upper site and was subject to minor impairment from organic loading and sedimentation. The lower site was severely impaired by sedimentation and suffered more serious but still minor impairment from organic loading.

Gallagher Creek. Diatom metrics suggest minor impairment from organic loading and sedimentation in Gallagher Creek. Otherwise, Gallagher Creek had normal metric values for a mountain stream.

Washington Creek. Diatom metrics suggest impairment from sedimentation at both sites on Washington Creek. Impairment was moderate at the upper site and severe at the lower site. Minor impairment from organic loading was indicated at both sites, which had identical pollution index values. The two sites on Washington Creek shared $43 \%$ of their diatom assemblages, which indicates a minor amount of environmental change.

Jefferson Creek. Both sites were subject to minor impairment from sedimentation. In addition, the lower site had minor impairment from organic loading. The dominant diatom species at the upper site (Epithemia sorex) indicates eutrophic but nitrogen-limiting conditions. The dominant species at the lower site (Melosira varians) indicates elevated concentrations of 
inorganic nutrients, including nitrogen and phosphorus. As in Washington Creek, the two sites shared $43 \%$ of their diatom assemblages.

Braziel Creek. Braziel Creek was subject to minor impairment from sedimentation. The siltation index approached but did not exceed the threshold for moderate impaiment. In other respects, Braziel Creek had normal metric values for a mountain stream.

Seven-Up Pete Creek. Aside from a few abnormal diatom cells, Seven-Up Pete Creek had excellent biological integrity for a mountain stream. However, this stream supported the smallest number of diatom species (36) of all the sites in the sample set.

\section{Modal Categories (Table 6)}

Several ecological attributes assigned by Stevenson and Van Dam et al. (1994) were selected from the diatom reports in the appendix. Modal categories of these attributes were extracted to characterize water quality tendencies in tributaries of the Blackfoot River (Table 6).

The majority of diatoms at most sites in the Blackfoot River TMDL planning area were non-motile, alkaliphilous, nitrogen autotrophs that prefer fresh waters, moderate BOD levels, high oxygen levels, and elevated concentrations of inorganic nutrients. However, the modal categories at some sites represent significant departures in water quality when compared to most other sites in the sample set. These departures, which may reflect increases or decreases in water quality, are discussed below.

Although most of the sites were dominated by non-motile diatoms, Blanchard Creek, Black Bear Creek, and the lower site on Washington Creek were dominated by highly motile diatoms. Meanwhile, Frazier Creek, the lower sites on Buffalo Gulch and Douglas Creek, and the upper site on Jefferson Creek were dominated by moderately motile diatoms. These sites are most likely to have sedimentation problems. 
Diatom species that prefer circumneutral (as opposed to alkaline) $\mathrm{pH}$ values were most abundant in Monture Creek and Kleinschmidt Creek. These streams are likely to have lower pH values than the other streams.

Nitrogen autotrophs were in the majority at all sites except lower Deer Creek, where facultative nitrogen heterotrophs accounted for the majority of the diatom cells. This site likely receives heavier loads of organic nitrogen than other sites in the sample set. At site 20 on the West Fork of the Clearwater River and site 10 on Rock Creek, most cells were represented by species that have not been classified with regard to nitrogen uptake.

The modal category for oxygen demand was "continuously high" at several sites. This is the nominal category for mountain streams. Most diatoms were in the "fairly high" category in Richmond Creek, Blanchard Creek, Wales Creek, the lower site on Washington Creek, and the upper site on Jefferson Creek. Moderate oxygen demand was the modal category at most of the remaining sites. Most cells were represented by species that have not been classified with regard to oxygen demand in lower West Fork Clearwater River, upper Rock Creek, Buffalo Gulch, and Seven-Up Pete Creek.

Beta-mesosaprobous was the usual level of saprobity at most sites. This represents a dissolved oxygen saturation level of $70-85 \%$ and a biochemical oxygen demand $\left(\mathrm{BOD}_{5}\right)$ of $2-4$ $\mathrm{mg} / \mathrm{L}$. However, saprobity levels were higher at three sites where most of the diatoms indicated more organic loading (alpha-mesosaprobous): Yourname Creek, lower Deer Creek, and lower Jefferson Creek. The alpha-mesosaprobous level corresponds to $25-70 \%$ saturation of dissolved oxygen and 4-13 mg/L BOD ${ }_{5}$. Saprobity levels were unclassified for the majority of diatoms in lower West Fork Clearwater River and upper Rock Creek.

Most sites in the Blackfoot River TMDL planning area were dominated by eutraphentic diatom species. Two sites-Wales Creek and Upper Deer Creek-were dominated by mesoeutraphentic species. Meso-eutraphentic is the next trophic level below (less enriched than) eutraphentic. Five sites were dominated by species that tolerate a wide range of trophic levels ranging from oligotrophic to eutrophic: Monture Creek (all sites), Kleinschmidt Creek, and 
lower Rock Creek. Trophic statts for the majority of diatoms remains unclassified in the lower

West Fork Clearwater River and upper Rock Creek.

\section{References}

APHA. 1998. Standard Methods for the Examination of Water and Wastewater. 20 ${ }^{\text {th }}$ Edition. American Public Health Association, Washington, D.C.

Bahls, L.L. 1979. Benthic diatom diversity as a measure of water quality. Proceedings of the Montana Academy of Sciences 38:1-6.

Bahls, L.L. 1993. Periphyton Bioassessment Methods for Montana Streams (revised). Montana Department of Health and Environmental Sciences, Helena.

Bahls, L.L., Bob Bukantis, and Steve Tralles. 1992. Benchmark Biology of Montana Reference Streams. Montana Department of Health and Environmental Sciences, Helena.

Barbour, M.T., J. Gerritsen, B.D. Snyder, and J.B. Stribling. 1999. Rapid Bioassessment Protocols for Use In Streams and Wadeable Rivers: Periphyton, Benthic Macroinvertebrates and Fish. Second Edition. EPA/841-B-99-002. U.S. Environmental Protection Agency, Office of Water, Washington, D.C.

Beaver, Janet. 1981. Apparent Ecological Characteristics of Some Common Freshwater Diatoms. Ontario Ministry of The Environment, Technical Support Section, Don Mills, Ontario.

Hieber, Maggi, C.T. Robinson, S. R. Rushforth, and Urs Uehlinger. 2001. Algal communities associated with different alpine stream types. Arctic, Antarctic, and Alpine Research 33(4):447-456.

Johansen, J.R. 1999. Diatoms of Aerial Habitats. Chapter 12 in Stoermer, E.F., and J.P. Smol (eds.), The Diatoms: Applications For the Environmental and Earth Sciences, Cambridge University Press, New York.

John, D.M., B.A. Whitton, and A.J. Brook (eds.). 2002. The Freshwater Algal Flora of the British Isles: An Identification Guide to Freshwater and Terrestrial Algae. Cambridge University

Karr, J.R., and D.R. Dudley. 198I. Ecological perspectives on water quality goals. Environmental Management 5:55-69.

Kawecka, B. 1990. The effect of flood-control regulation of a montane stream on the communities of sessile algae. Acta Hydrobiology 32:345-354.

Krammer, Kurt. 1997a. Die cymbelloiden Diatomeen: Eine Monographie der weltweit bekannten Taxa. Teil 1. Allgemeines and Encyonema Part. J. Cramer, Berlin.

Krammer, Kurt. 1997b. Die cymbelloiden Diatomeen: Eine Monographie der weltweit bekannten Taxa. Teil 2. Encyonema part., Encyonopsis and Cymbellopsis. J. Cramer, Berlin.

Krammer, Kurt. 2002. Cymbella. Volume 3 in Diatoms of Europe, Horst Lange-Bertalot, ed. A.R.G. Gantner Verlag K.G., Germany.

Krammer, K., and H. Lange-Bertalot. 1986. Bacillariophyceae, Part 2, Volume 1: Naviculaceae. In Ettl, H., J Gerloff, H. Heynig, and D. Mollenhauer (eds.), Freshwater Flora of Middle Europe. Gustav Fischer Publisher, New York. 
Krammer, K., and H. Lange-Bertalot. 1988. Bacillariophyceae, Part 2, Volume 2: Bacillariaceae, Epithemiaceae, Surirellaceae. In Ettl, H., J. Gerloff, H. Heynig, and D. Mollenhauer (eds.), Freshwater Flora of Middle Europe. Gustav Fischer Publisher, New York.

Krammer, K., and H. Lange-Bertalot. 1991 a. Bacillariophyceae, Part 2, Volume 3: Centrales, Fragilariaceae, Eunotiaceae. In Ettl, H., J. Gerloff, H. Heynig, and D. Mollenhauer (eds.), Freshwater Flora of Middle Europe. Gustav Fischer Publisher, Stuttgart.

Krammer, K., and H. Lange-Bertalot. $199 \mathrm{lb}$. Bacillariophyceae, Part 2, Volume 4: Achnanthaceae, Critical Supplement to Navicula (Lineolatae) and Gomphonema, Complete List of Literature for Volumes 1-4. In Ettl, H., G. Gartner, J. Gerloff, H. Heynig, and D. Mollenhauer (eds.), Freshwater Flora of Middle Europe. Gustav Fischer Publisher, Stuttgart.

Lange-Bertalot, Horst. 1979. Pollution tolerance of diatoms as a criterion for water quality estimation. Nova Hedwigia 64:285-304.

Lange-Bertalot, Horst. 1993. 85 new taxa and much more than 100 taxonomic clarifications supplementary to Susswasserflora von Mitteleuropa Vol. 2/1-4. J. Cramer, Berlin.

Lange-Bertalot, Horst. 1996. Rote Liste der limnischen Kieselalgen (Bacillariophyceae) Deutschlands. Schr.-R. f. Vegetationskde., H. 28, pp. 633-677. BfN, Bonn-Bad Godesberg.

Lange-Bertalot, Horst. 2001. Navicula sensu stricto: 10 Genera Separated from Navicula sensu lato; Frustulia. Volume 2 in Diatoms of Europe, Horst Lange-Bertalot, ed. A.R.G. Gantner Verlag K.G., Germany.

Lowe, R.L. 1974. Environmental Requirements and Pollution Tolerance of Freshwater Diatoms. EPA-670/4-74-005. U.S. Environmental Protection Agency, National Environmental Research Center, Office of Research and Development, Cincinnati, Ohio.

McFarland, B.H., B.H. Hill, and W.T. Willingham. 1997. Abnormal Fragilaria spp. (Bacillariophyceae) In streams impacted by mine drainage. Journal of Freshwater Ecology 12(1):141-149.

Nicholls, K.H., and D.E.Wujek. 2003. Chrysophycean Algae. Chapter 12 (pp. 471-509) in Wehr, J.D., and R.G. Sheath (eds.), Freshwater Algae of North America: Ecology and Classification. Academic Press, New York.

Palmer, C.M. 1969. A composite rating of algae tolerating organic pollution. Journal of Phycology 5:78-\$2.

Palmer, C.M. 1977. Algae and Water Pollution: An fllustrated Manual on the Identification, Significance, and Control of Algae in Water Supplies and in Polluted Water. EPA-600/9-77-036.

Plafkin, J.L., M.T. Barbour, K.D. Porter, S.K. Gross, and R.M. Hughes. 1989. Rapid Bioassessment Protocols for Use in Rivers and Streams: Benthic Macroinvertebrates and Fish. EPA 440-4-89-001.

Prescott, G.W. 1962. Algae of the Western Great Lakes Area. Wm. C. Brown Company, Dubuque, Iowa.

Prescott, G.W. 1978. How to Know the Freshwater Algae. Third Edition. Wm. C. Brown Company Publishers, Dubuque, Iowa.

Reichardt, Erwin. 1997. Taxonomische Revision des Artenkomplexes um Gomphonema pumilum (Bacillariophyta). Nova Hedwigia 65(1-4):99-129.

Reichardt, Erwin. 1999. Zur Revision der Gattung Gomphonema. A.R.G. Gantner Verlag, Distributed by Koeltz Scientific Books, Konigstein, Germany. 
Renfro, H.B., and D.E. Feray. 1972. Geological Highway Map of the Northern Rocky Mountain Region. American Association of Petroleum Geologists, Tulsa, Oklahonia.

Smith, G.M. 1950. The Fresh-Water Algae of The United States. McGraw-Hill Book Company, New York.

Stevenson, R.J., and Y. Pan. 1999. Assessing Environmental Conditions in Rivers and Streams with Diatoms. Chapter 2 in Stoermer, E.F., and J.P. Smol (eds.), The Diatoms: Applications For the Environmental and Earth Sciences, Cambridge University Press, New York.

Stewart, W.D.P., P. Rowell, and A.N. Rai. 1980. Symbiotic Nitrogen-Fixing Cyanobacteria. Pp. 239-277 in Stewart, W.D.P., and J. Gallo (eds.), Nitrogen Fixation, Academic Press, New York.

USDA. 1976. Climax Vegetation of Montana (map). U.S. Department of Agriculture, Soil Conservation Service, Cartographic Unit, Portland.

USEPA. 2000. Level III Ecoregions of the Continental United States (map). National Health and Environmental Effects Research Laboratory, U.S. Environmental Protection Agency, Corvallis, Oregon.

Van Dam, Herman, Adrienne Mertens, and Jos Sinkeldam. 1994. A coded checklist and ecological Indicator values of freshwater diatoms from The Netherlands. Netherlands Journal of Aquatic Ecology 28(1):117-133.

Weber, C.I. (ed.). 1973. Biological Field and Laboratory Methods for Measuring the Quality of Surface Waters and Effluents. EPA-670/4-73-001. U.S. Environmental Protection Agency, National Environmental Research Center, Office of Research and Development, Cincinnati, Ohio.

Wehr, J.D., and R.G. Sheath. 2003. Freshwater Algae of North America: Ecology and Classification. Academic Press, New York.

Whittaker, R.H. 1952. A study of summer foliage insect communities in the Great Smoky Mountains. Ecological Monographs 22:1-44.

Woods, A.J., Omernik, J.M., Nesser, J.A., Shelden, J., and S.H. Azevedo. 1999. Ecoregions of Montana (color poster with map), U.S. Geological Survey, Reston, Virginia. 


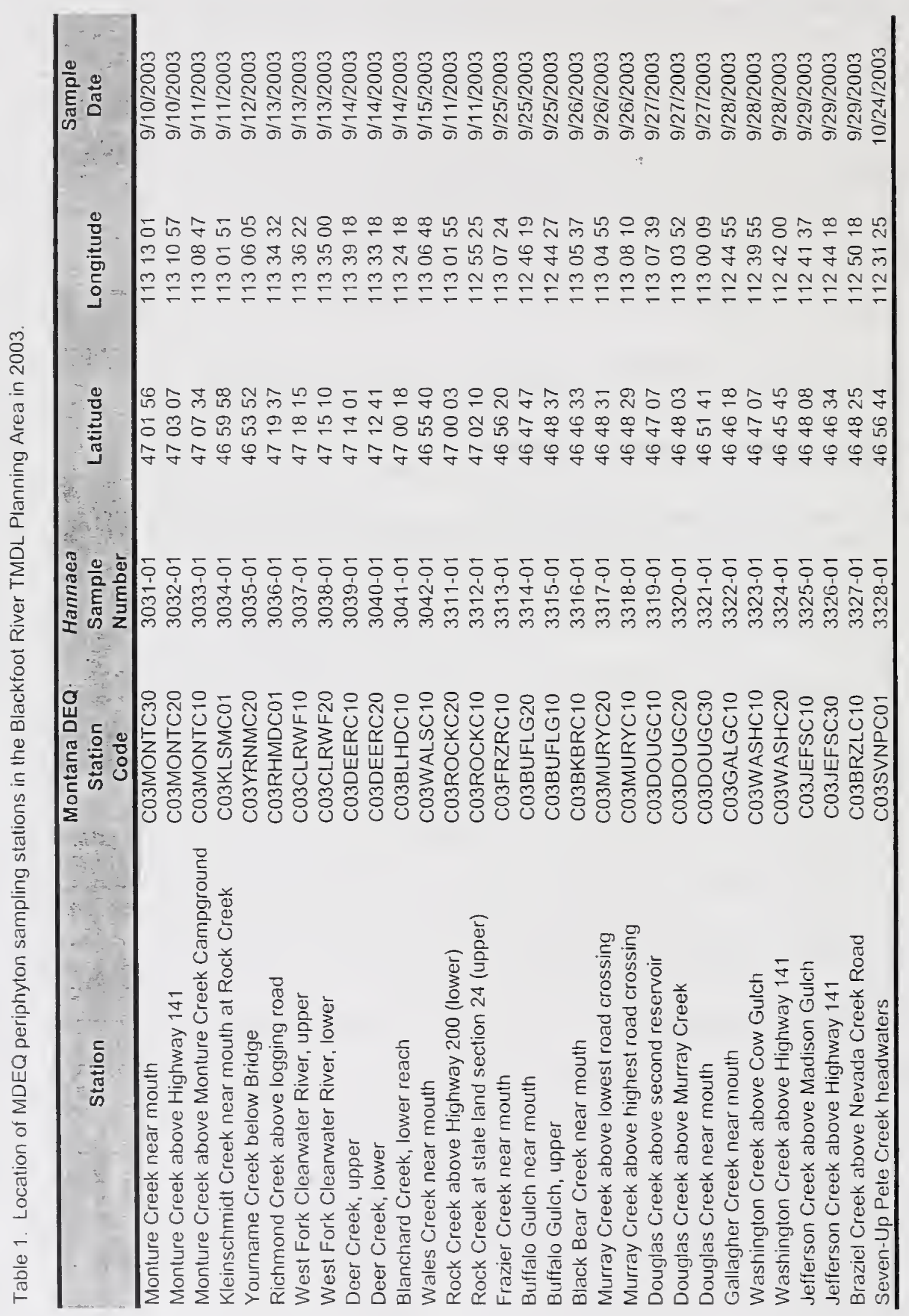




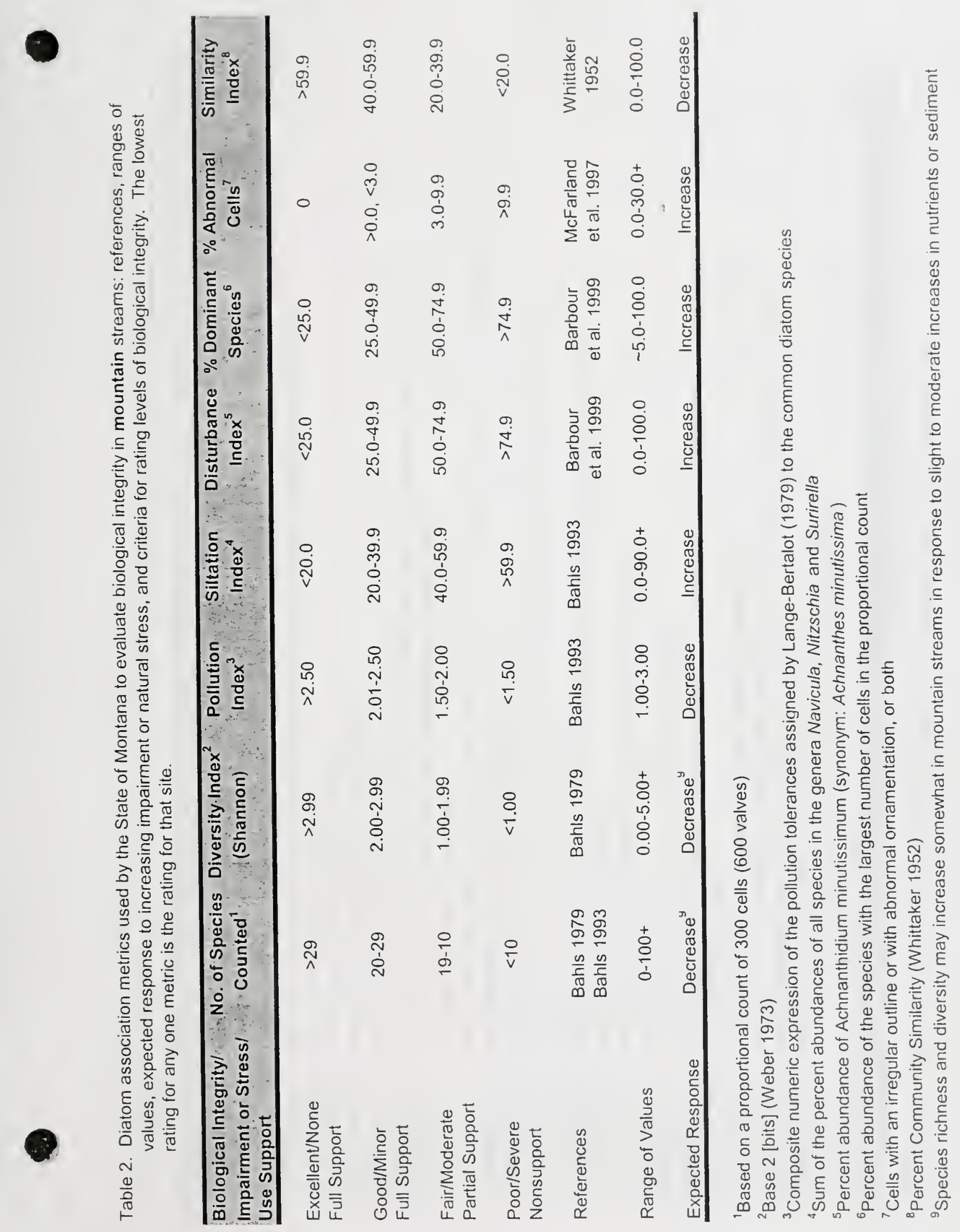




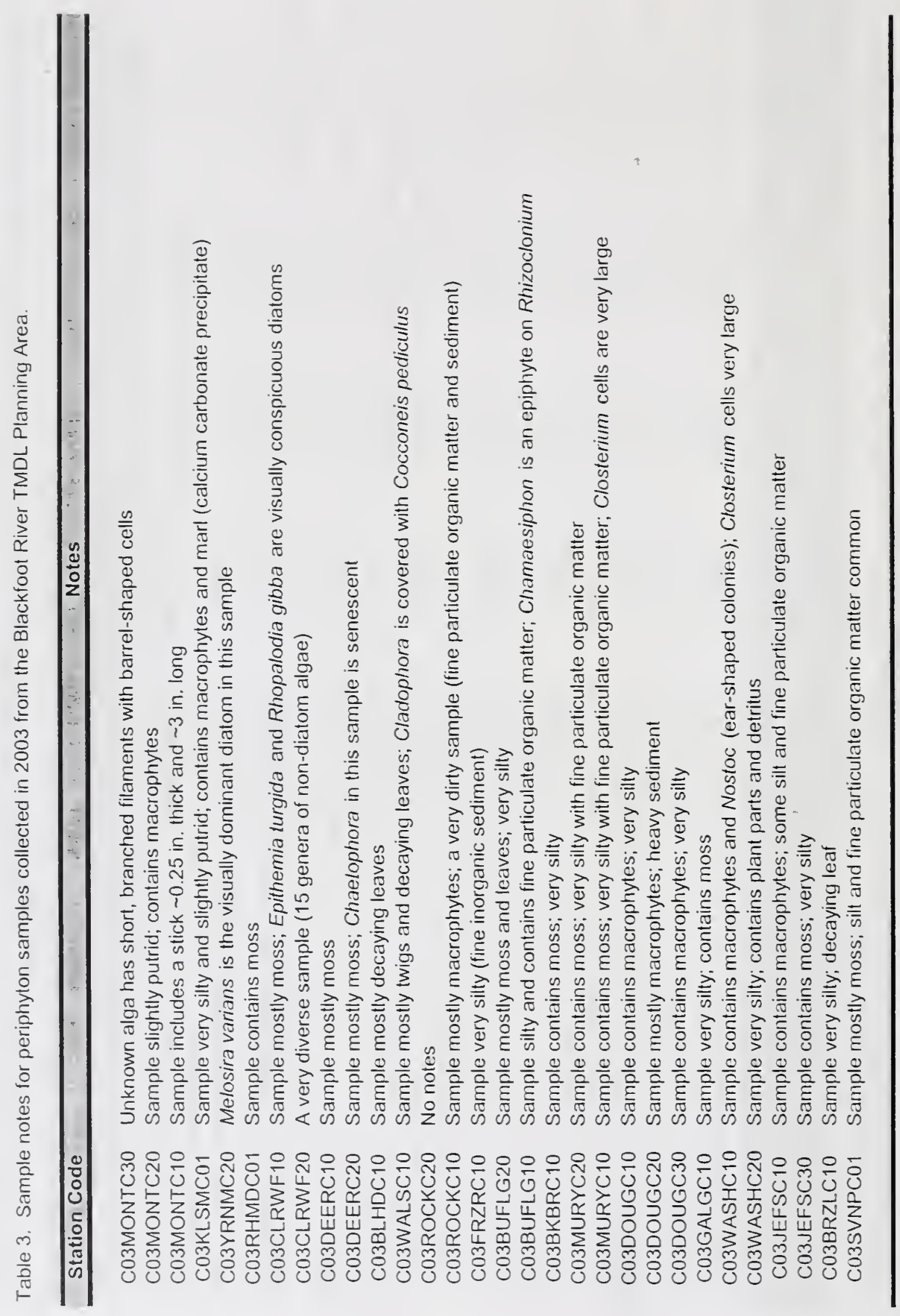




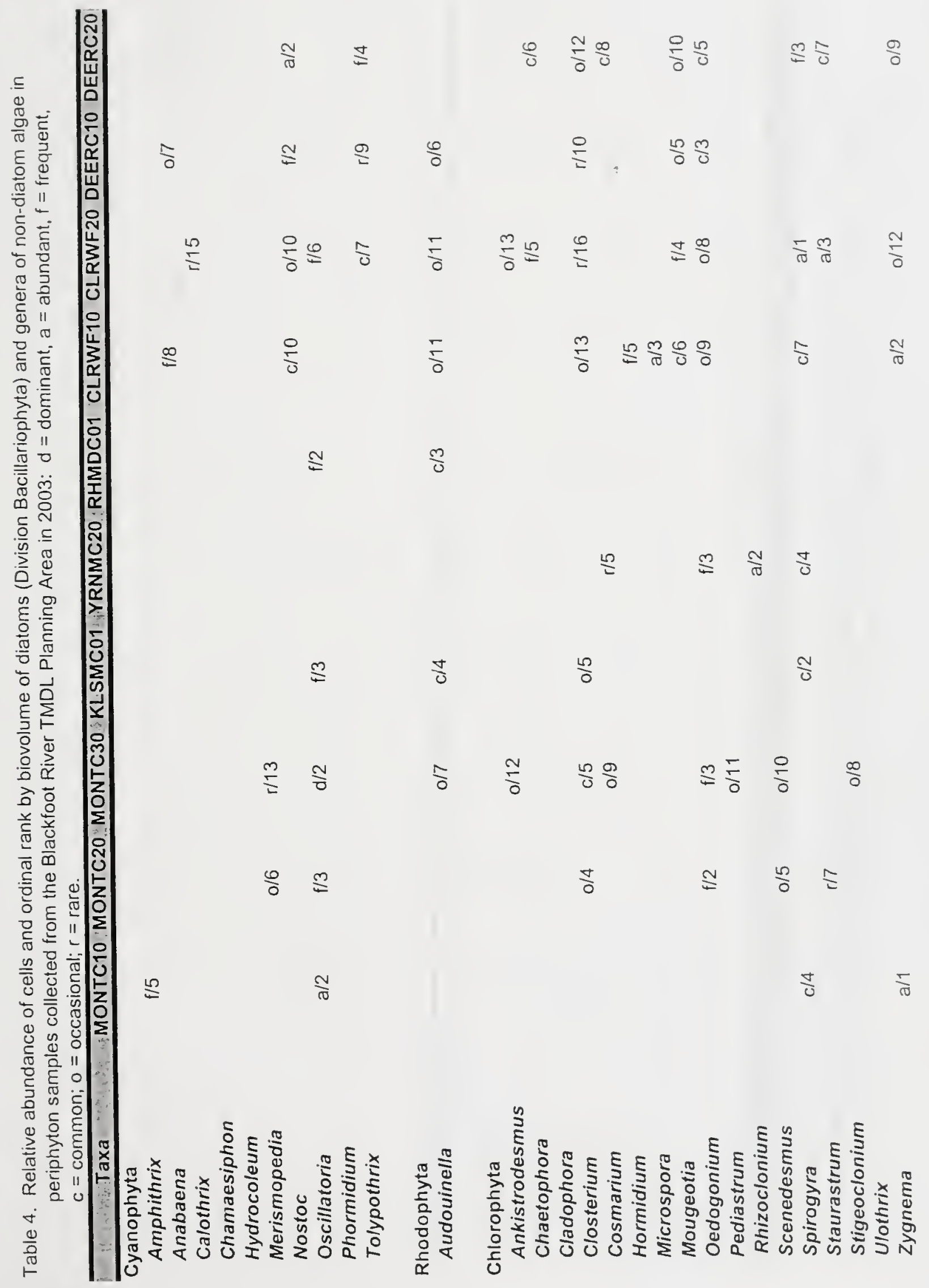




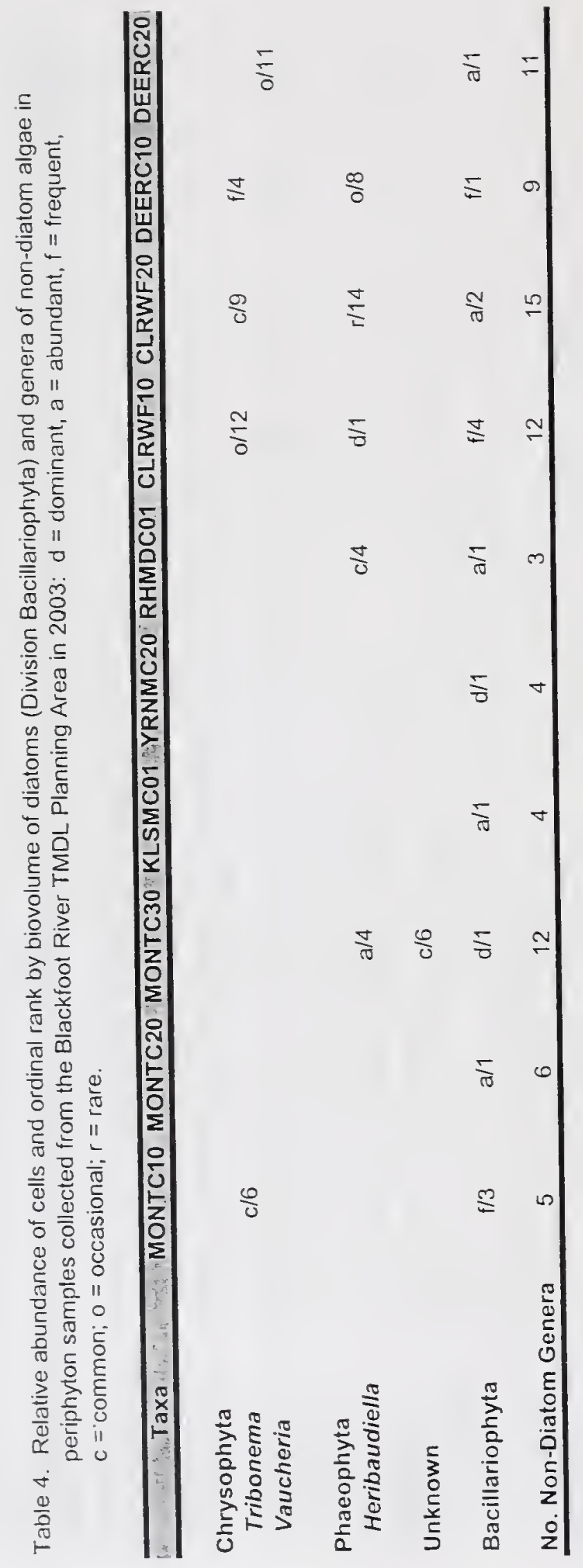




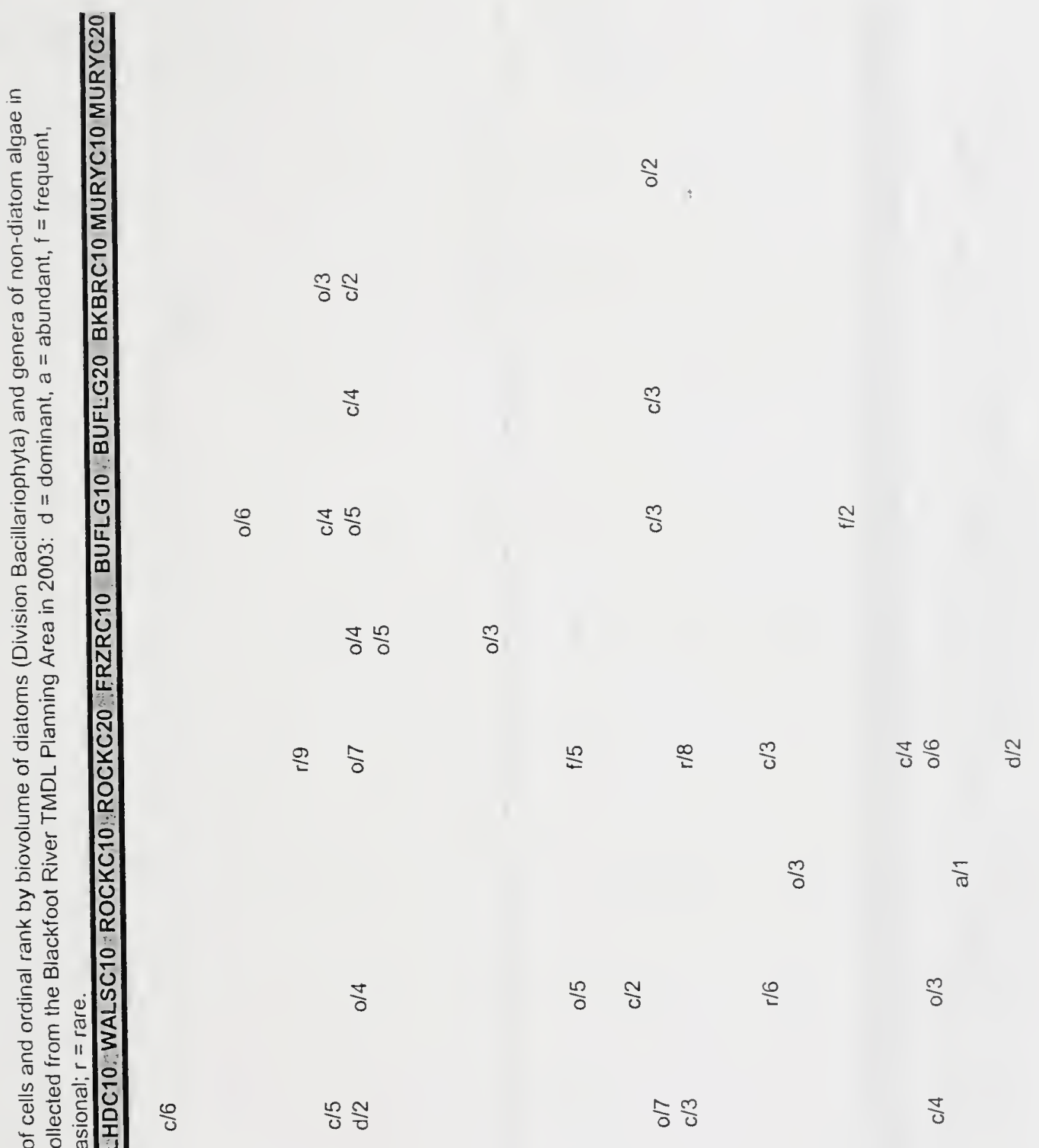




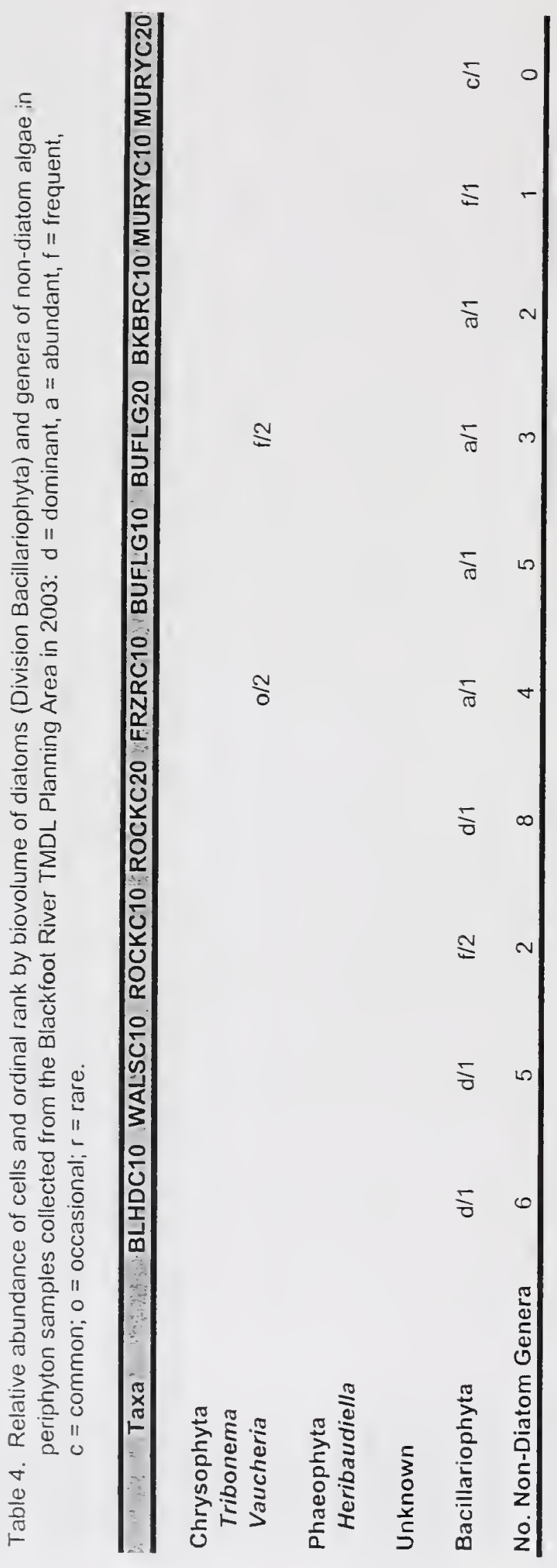




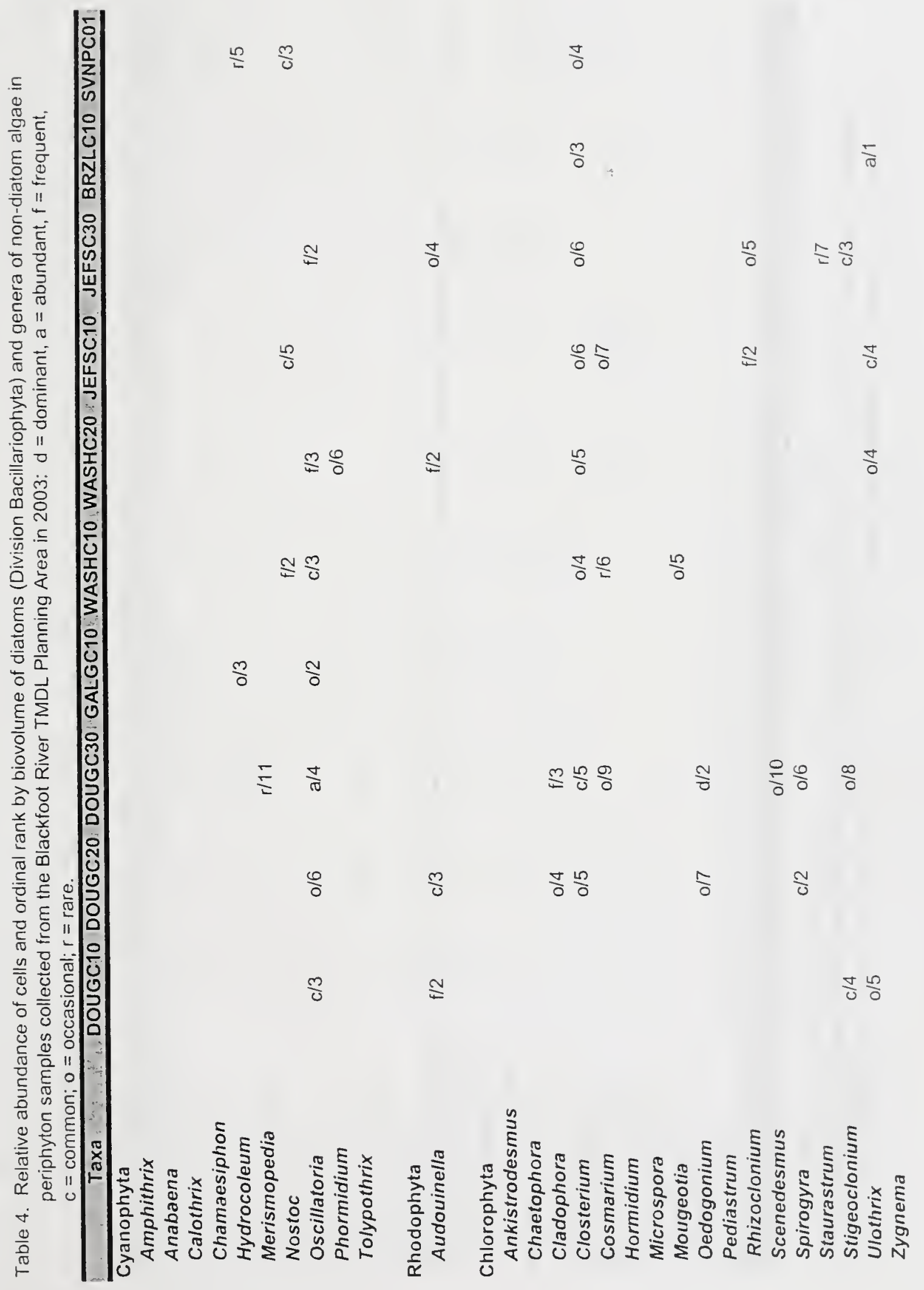




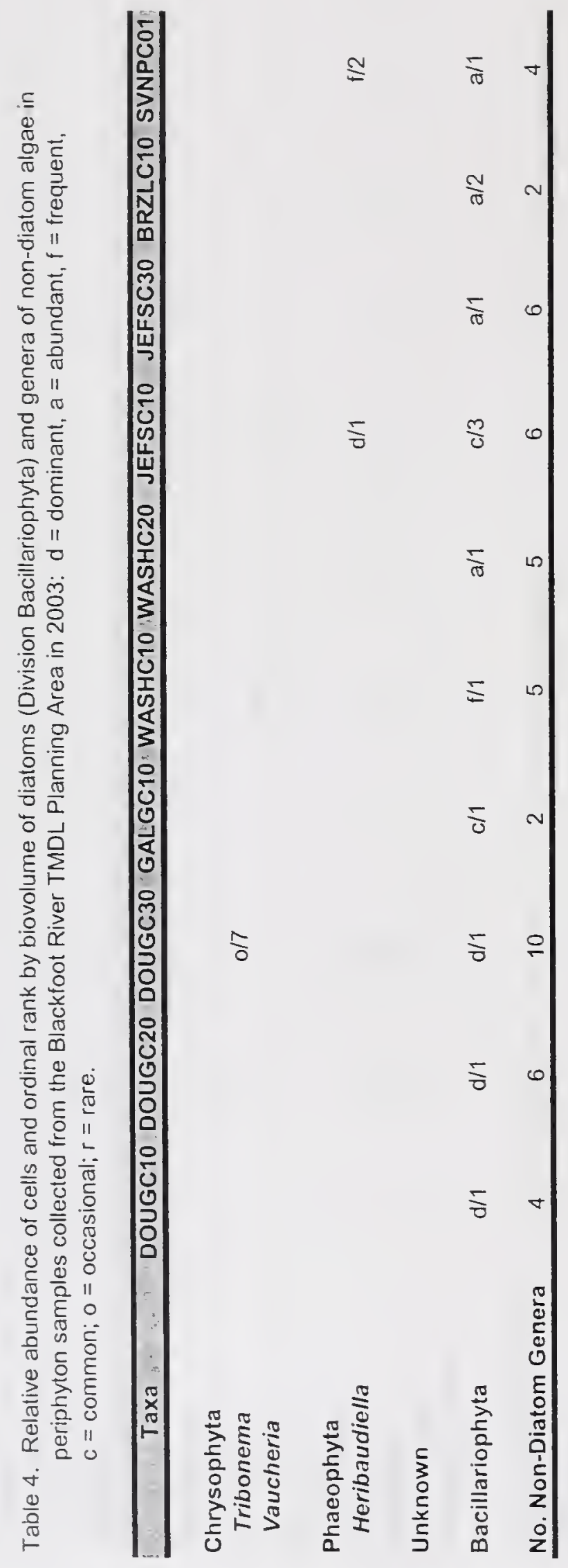




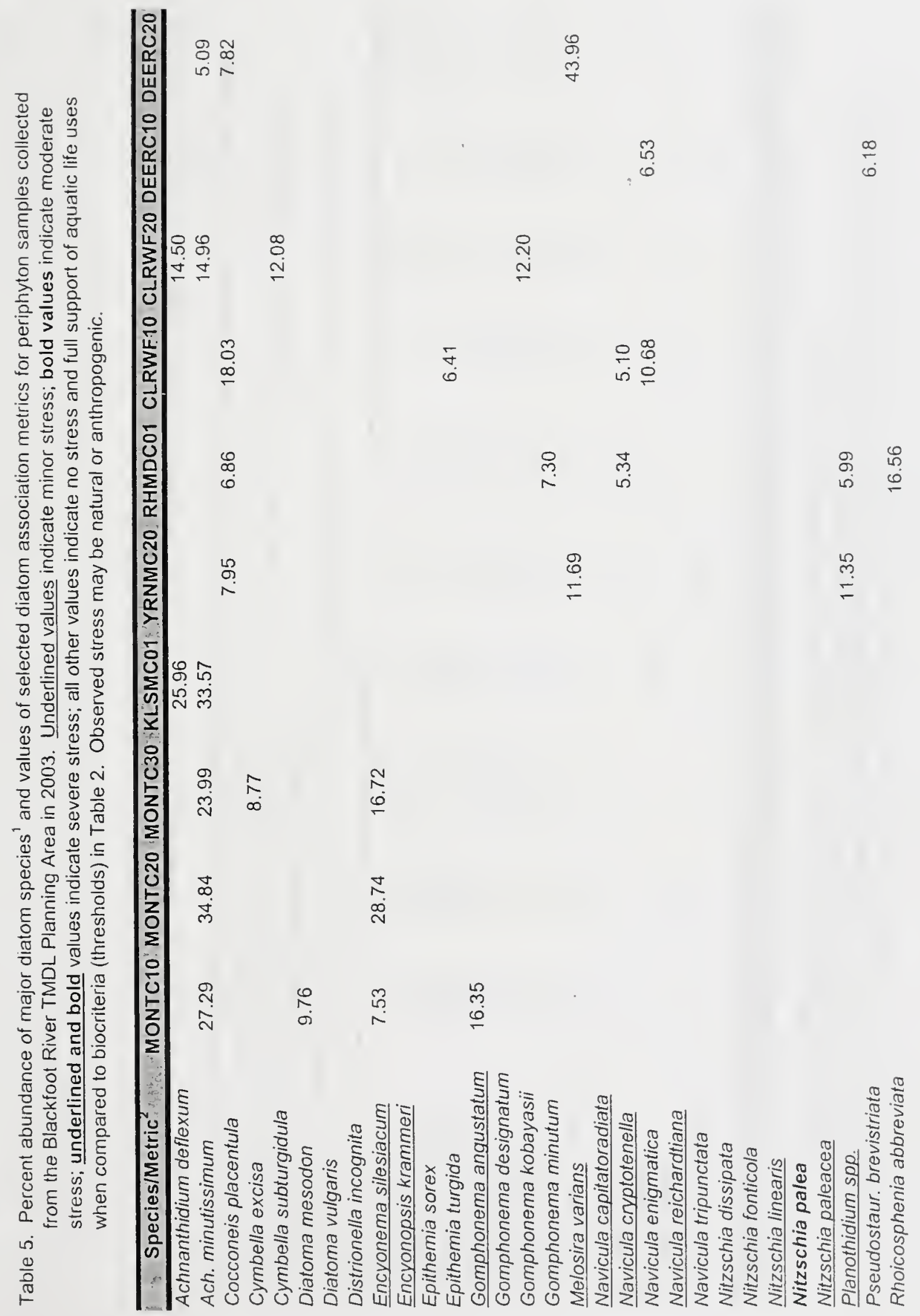




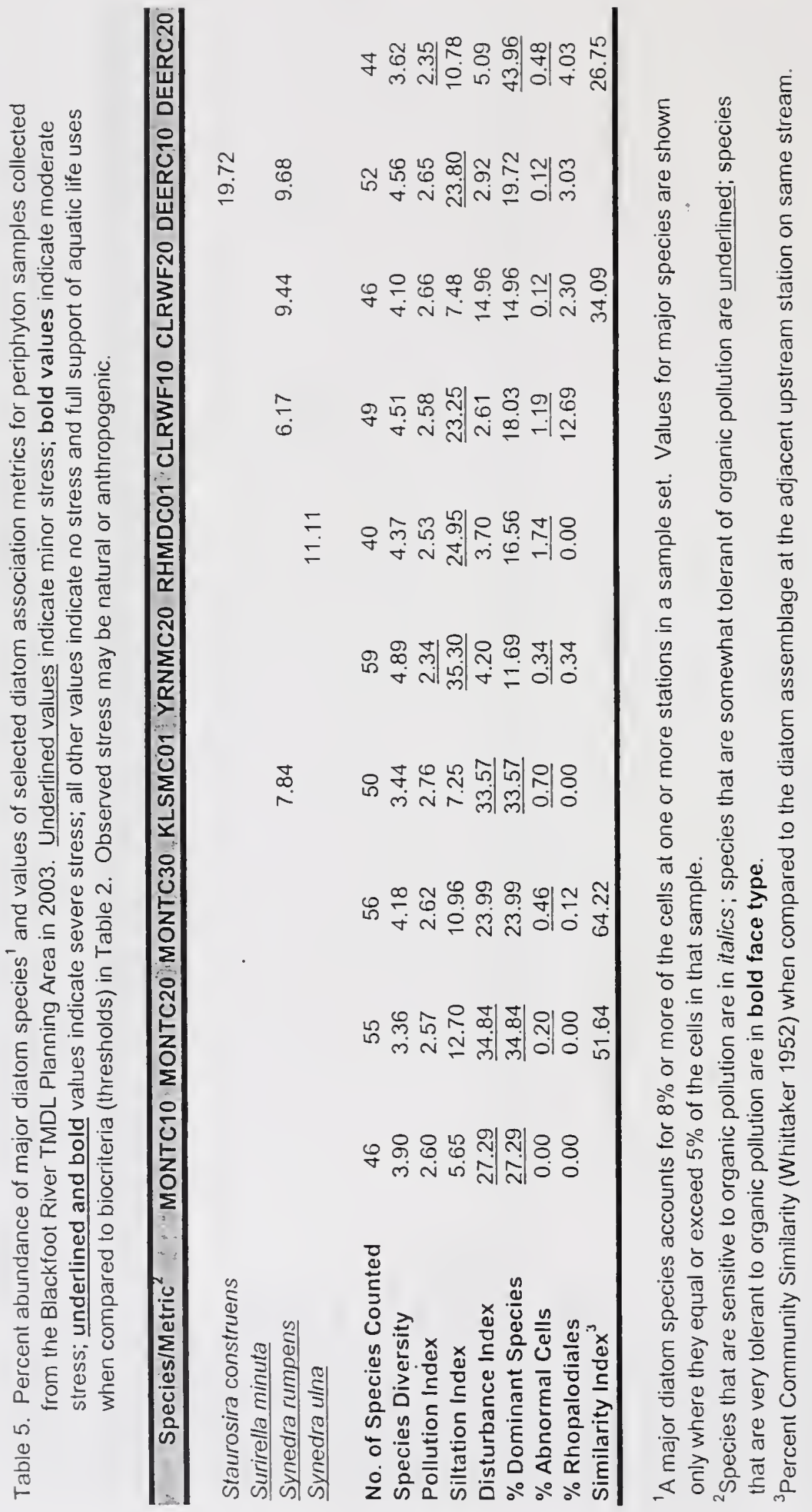




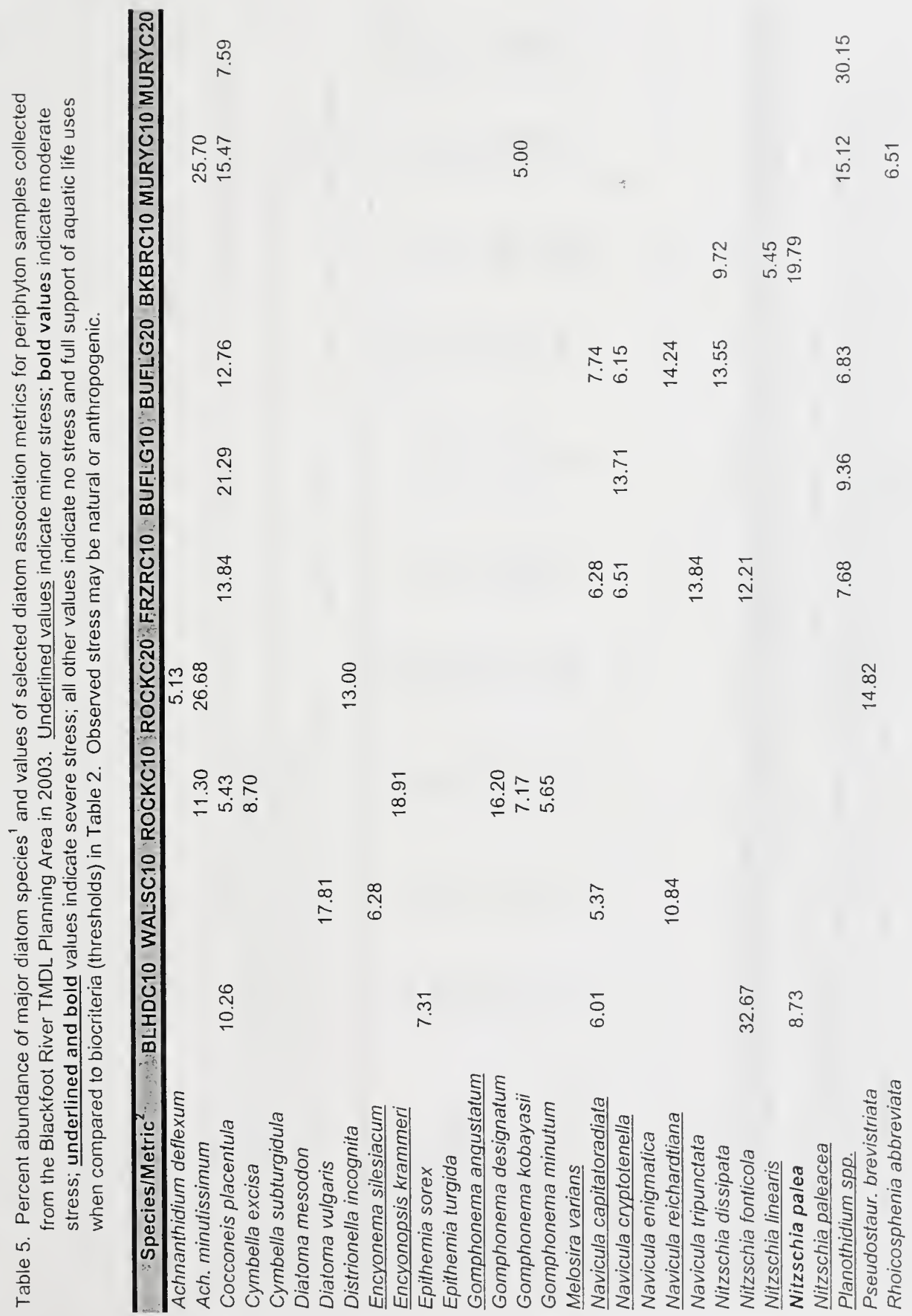




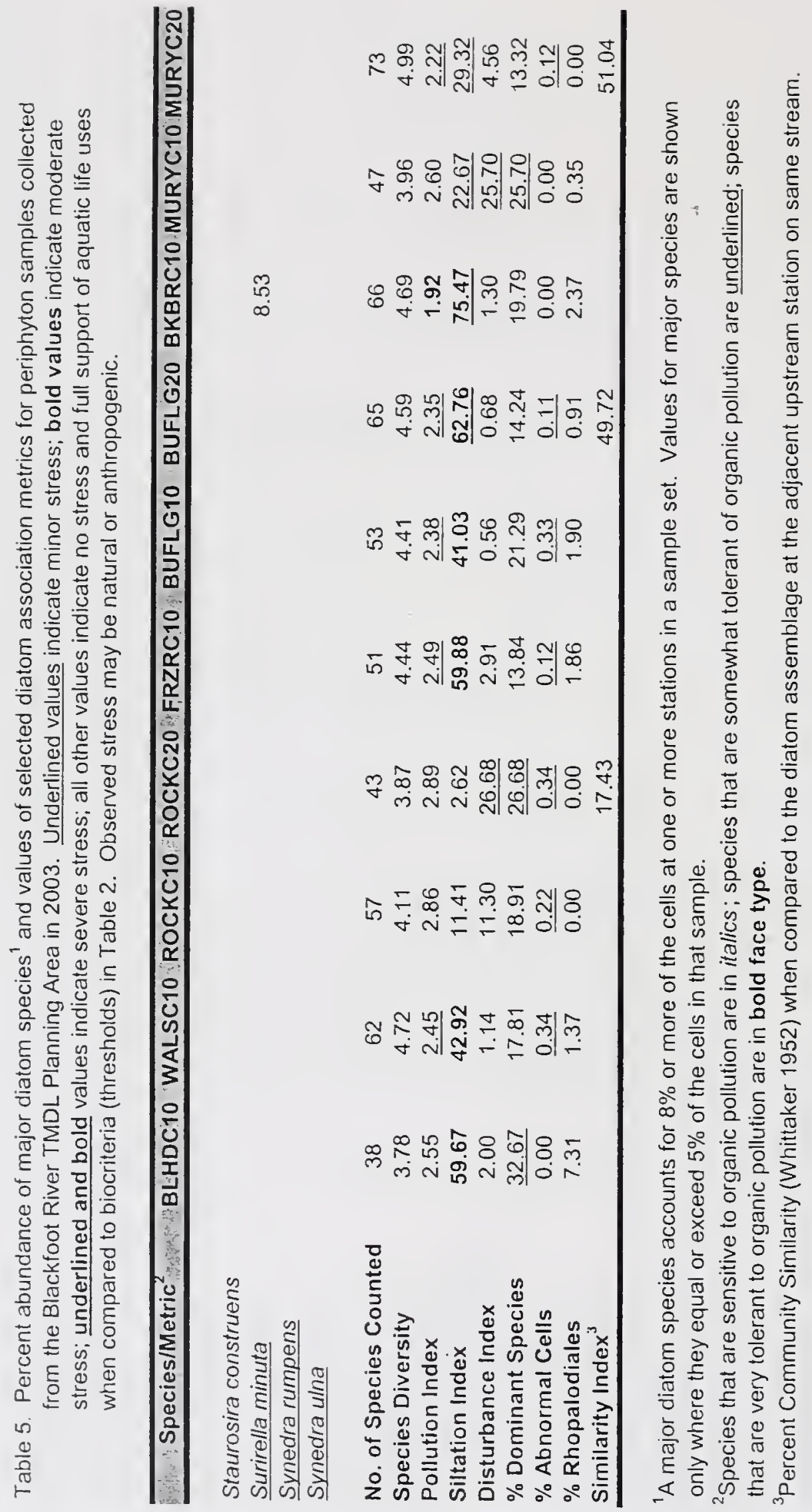




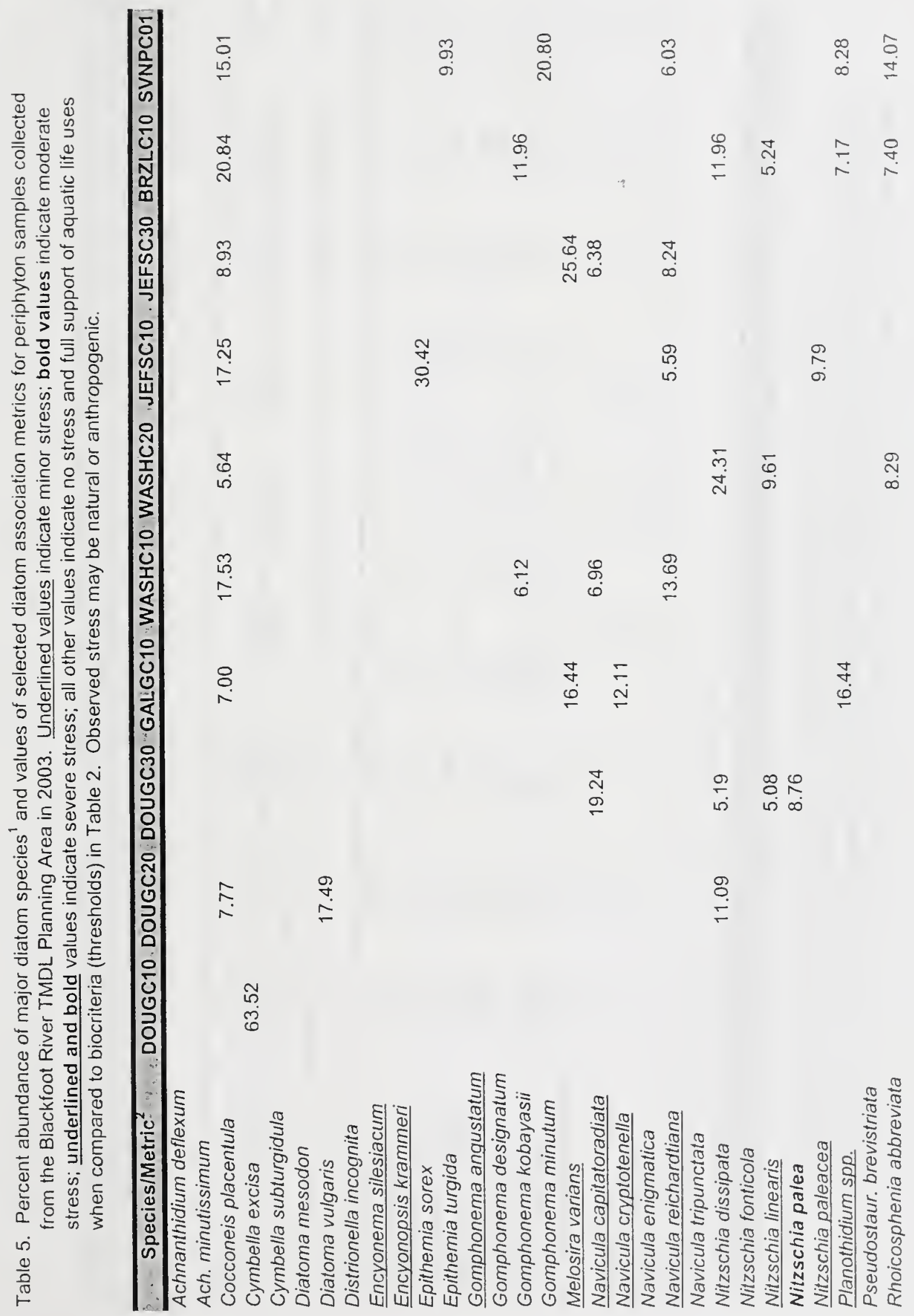


ल

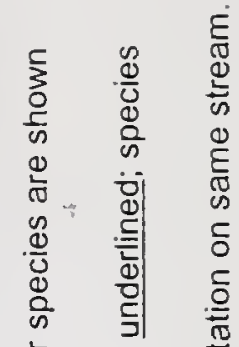

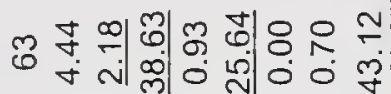

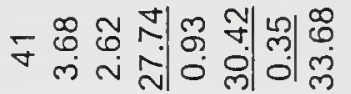

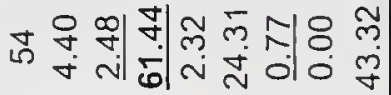

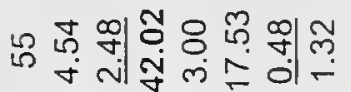

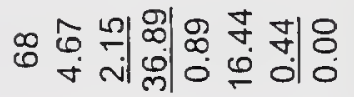

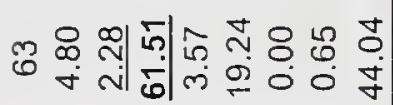

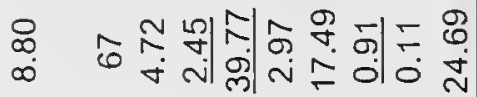
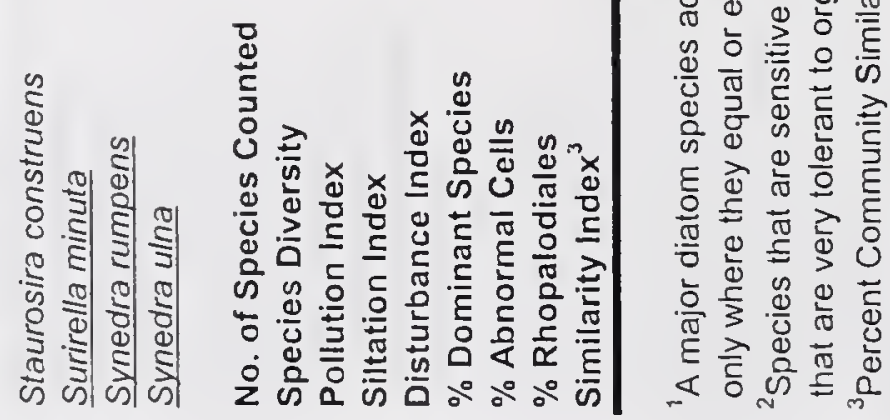

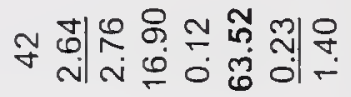




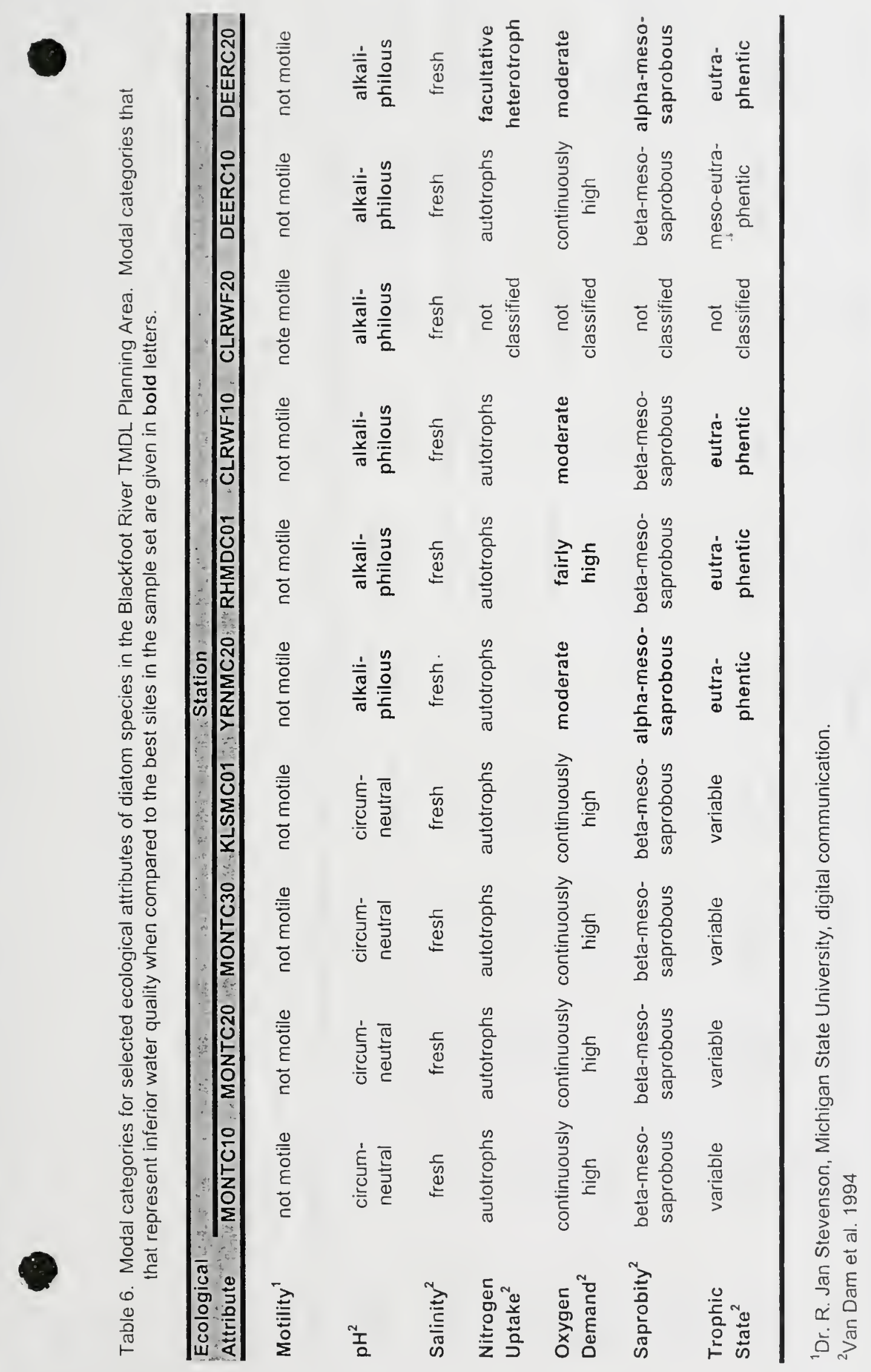




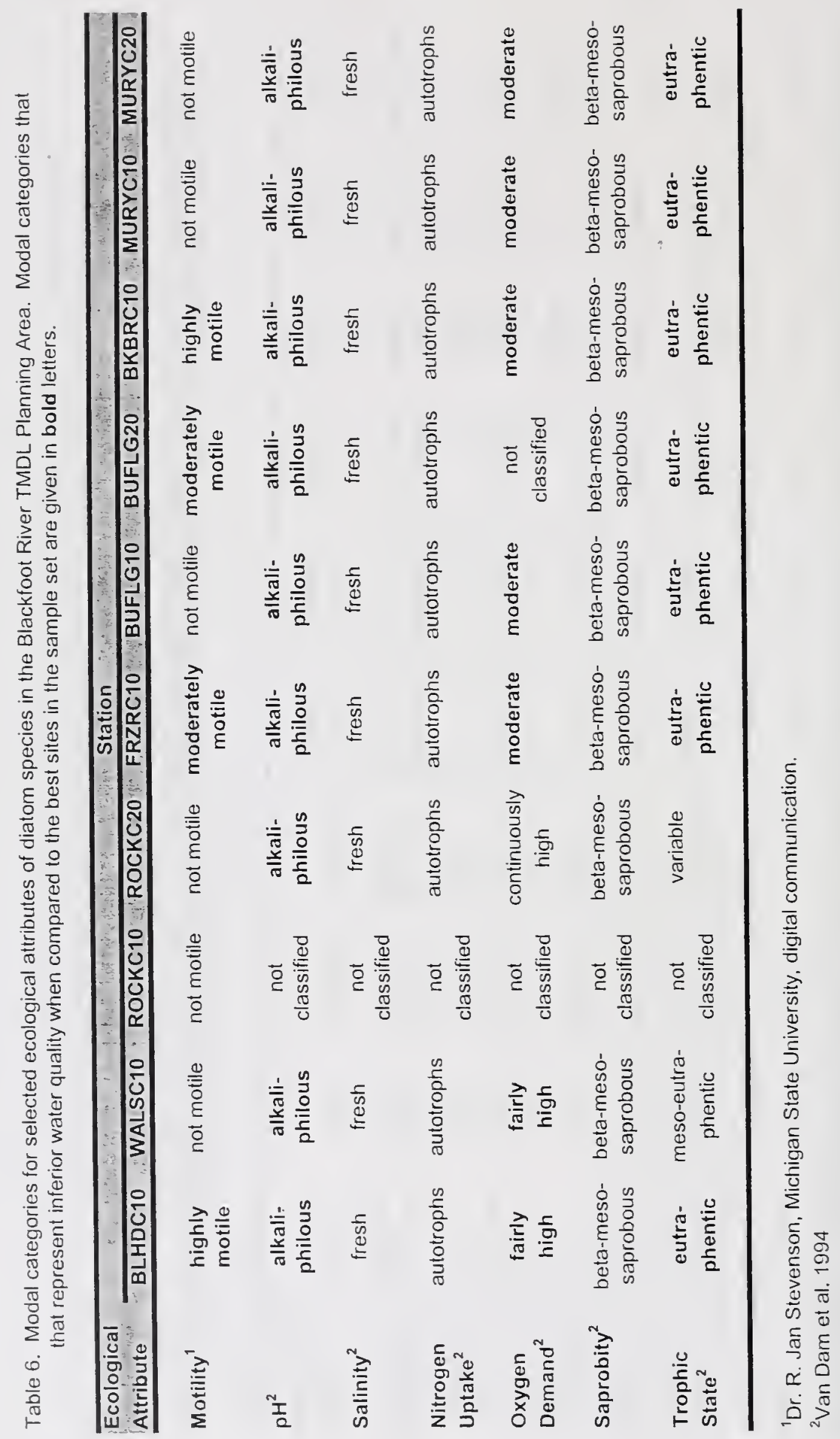




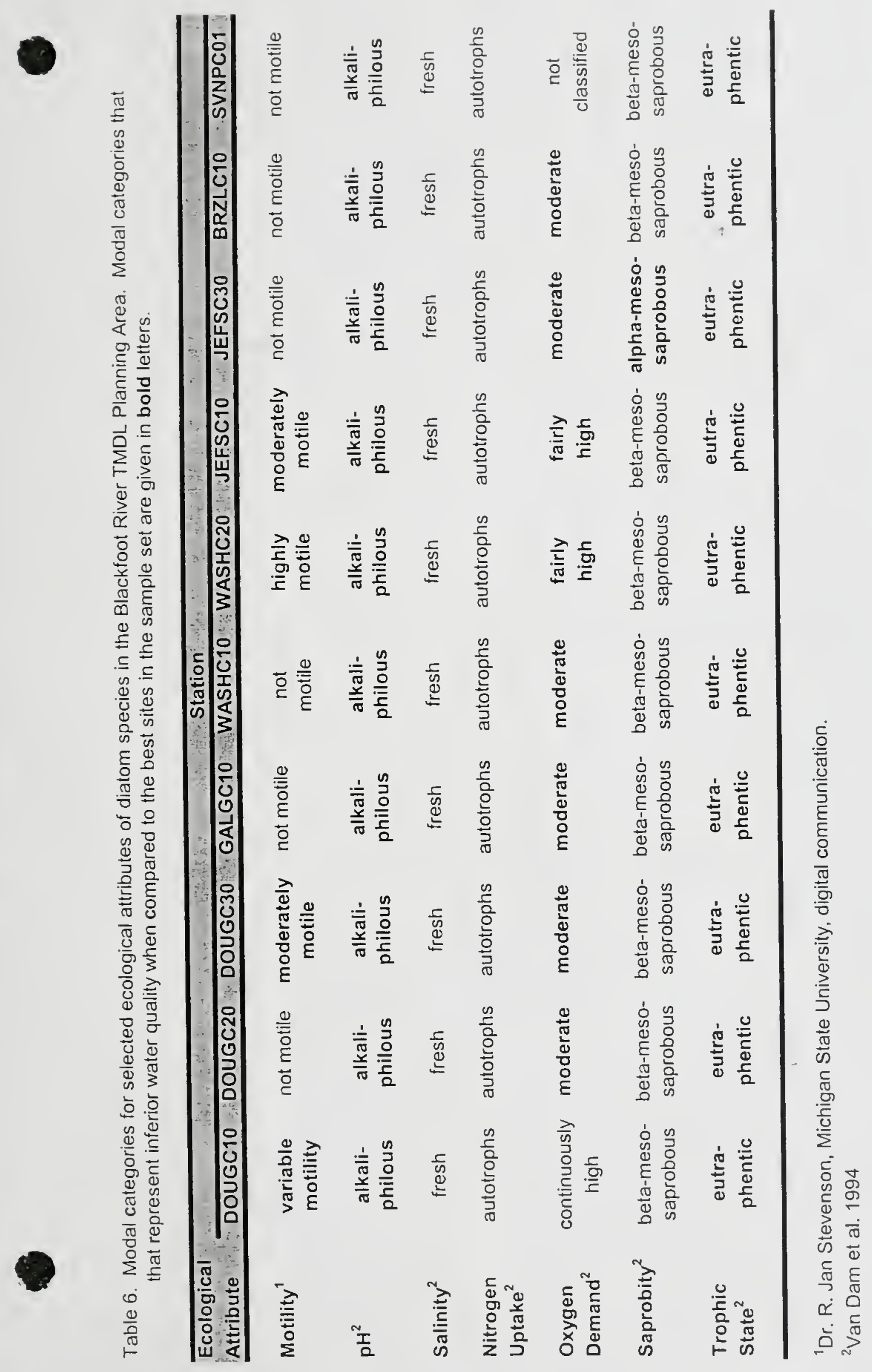


